\title{
Prioritising Or Postponing?” Thematic Analysis Of Reproductive And Motherhood Choices Among Educated Indian Married Women
}

\author{
Smita Gupta ${ }^{1}$,Namita S Malik ${ }^{2}$ \\ ${ }^{1}$ Associate Professor, School of Law, Delhi Metropolitan Education, Guru Gobind Singh Indraprastha University, B- 12, Sector \\ 62, Noida - 201301, India \\ ${ }^{2}$ Associate Professor, School of Law, Galgotias University, Plot No. 2, Yamuna Expressway, Sector 17 A, Greater Noida - \\ 20320, India \\ Email:12dr.smita.gupta10@gmail.com, ${ }^{2}$ namitasmalik@gmail.com
}

\begin{abstract}
This paper attempts to understand and explains the intersection of reproductive and motherhood choices among educated working and nonworking married women in India. The choices women pick in realm of sociological, cultural and religious controls have been largely silenced in literature.

This phenomenological study looks into lives of 20 married educated Indian women and their reproductive and motherhood choices. With the help of semi-structured questionnaire, 20 women, predominantly educated middle class women, have been interviewed. A thematic analysis using a grounded approach has been used to analyse the qualitative data obtained from these 20 women. Two dominant themes emerged in the systematic qualitative review. Among educated working women, voices of career goals, self-accomplishments, and career promotions were the major theme manifested while exercising their reproduction choice. On the other hand, theme emerged among educated non-working mothers were enhancement in social influence, stability and social pressure. Study revealed the stress and social tensions embedded in exercising reproductive choice con-joined with family influences, economic priorities, career and biological clock urge.

The study further describes how increase in technological advancements and modernism has not affected largely sphere of women reproductive choices and changed social perception of motherhood; rather complicated dilemmas for her.
\end{abstract}

Keywords

Motherhood, Reproductive choices, Married women, India.

Article Received: 10 August 2020, Revised: 25 October 2020, Accepted: 18 November 2020

\section{Introduction}

When discriminating between the human world and the inanimate world, a central role is played by the fact that the sequences in which people interact are fragmentary: each person supplies part of the total behaviour-the child reaches up and the adult wraps him/her in an embracewhile the instrumental behaviour with objects always implies performing a complete sequence. This "completeness" feature in the experiences with objects and the "incompleteness" feature in the case of personal interactions foster the development of two different kinds of symbolization processes, one based in action schemes and the other in interaction patterns (Wolf \& Gardner, 1981)

Femininity or masculinity of a person is a result of intersubjectivity and interplay of attitudes and societal idealization. Gender scheme is coded in human brains since birth and is a powerful expression. The process of gender code is at work from the time human being is born, through fantasies and expectations of femininity or masculinity. These gender expressions are a representation of conscious and unconscious minds, gestures and their meanings, with their own fantasies. The first symbols of infant are embedded in action and interaction; the first gendered expression of an infant is that of mummy and daddy, with further examples of baby girl playing with dolls while baby boy entertaining him with cars. These differential representations expressed in symbolic games signify interaction sequences, which are then passed from one generation to another; contributing in preparing the foundation of societal attitudes and perspectives on motherhood.
Motherhood in twenty first century encounters various challenges; Single mothers , Surrogate mothers, Working mothers (where mother and child relation is almost minimal due to very busy schedules of working mother), Transnational mothers (where a mother is connected through technology to her child who is miles away), Teenage mothers, Homosexual Mothers, or Motherhood acquired by way of reproductive techniques.

The situational contexts in which a mother has a child or a condition in which she does not have a child, or do not want to have a child are significant aspects to be studied. Consciously or unconsciously, motherhood ideals are given by society and individual perspectives. With every generation, idealized conventional notion gets assimilated and influence female thoughts related to motherhood. In many societies the representation of women is expressed in the state of motherhood which does include and overshadows their self -representation. The primary representation of women includes her preoccupation in rearing a child physically, emotionally and socially along with her availability to attend the child; and all values which are inherent in goodness of mother. These inherent morals of mother run down through generations and frames conduct of a mother and behaviour in pre-conscious and unconscious mind.

It is unimaginable that a good mother will get baffled over conflicts between work, home and self-imposed roles. It is not fit for the mother to let these conflicts outburst in form of anger and frustrations towards child. Such expressions of anger and hatred are not suited to good mother's image. On the other hand, yearning to have a child is the unconscious 
response to a role which women wish to incarnate in terms of motherhood among societal and family pressures.

In traditional Indian society identification and its subjectivity of gender expressions are associated since the beginning of life. When expected parents hope for a baby boy, they complement with one who would take care of them in their old age and if it is a baby girl, they sequence with vast expenses which shall occur for her marriage. Society raises girl child and boy child with attitudes and activities that generate a dimorphic response in the child. Parents configure their child identity and continuously enact their fantasies around femininity and masculinity. They wish to see their daughters as obedient, submissive, and trained in all virtues for being a woman. An ideal daughter, perfect wife and kind mother are precipitated from tradition, culture and social perceptions. This kind of extreme projective identification and idealization shapes the outright demand that mothers must be perfect and must not know any flaw.

The socio-political backdrop of India has dual standards, wherein women concern are expected to be centred around family and men expected to be skilled in outwardly affairs. It is the domain of men to get associated with outside world in-order to accomplish economic, social, and political order. On the contrary, an Indian woman had to face hostile or contradictory social standards. Her mobility is restricted many times in the name of family, social, cultural or religious norms. Family being a social group, a social system and a social institution (Eshleman, 2003) shapes the outline of a pysche of the women. This social institution has an imperative role to play in developing thought process of every person. The girl's identity after marriage - identity of a woman, a wife, and a mother is constructed for her, through family and the encompassing social systems (Rahmani \& Tayebinia, 2018).

In same way motherhood and reproductive roles are shaped in social and cultural processes. As a result of such processes, Indian women have internalised the thought which goes deep into their sub conscious that reproduction and motherhood is a major goal of marriage. Although the feminist disagree with this internalised belief asserting that "For feminist, the family and domestic sphere is the site of reproductive activities has long been the root cause of women's subordination." (Hayami, 1998)

Indian societal perception of an ideal moralistic family completely revolves around women as the centre of circumference - how well they can perform the roles of moral guardians, domestic managers, and national producers. Gender roles associated with division of labour is itself full of ambiguity in this realm of discourse. Although household work such as preparing food, washing and cleaning, nurturing kids, is not expressly explicit in gendered terms but still women in India are primarily responsible for accomplishing these tasks. In practice, the sphere of activities for men and women are quite differentiated. Boys and men are majorly responsible to take up jobs and earn bread for the family. This gendered differentiation of activities reflects the different processes of preparing men and women for adapting to marital life.

For Indian women, marriage brings a prominent change of status, marked by the dramatic change of costumes and mounted expectations of in-law's family in several ways. A woman is the power centre for all social religious and domestic influences. The nature and sphere of women's activities and social obligations greatly differs before and after marriage. Yoko Hayami has rightly pointed out that women's activities are centred on the "domestic" realm, which provides for their status in the wider community, and their reproductive roles define and reinforce their productive activities (Hayami, Motherhood Redefined, 1998). A woman being a progenitor has the major role to play in the reproductive cycle. Indian married women's reproductive roles appear very 'natural' after marriage and their prestige in family is escalated on attaining motherhood.

The fast changing social, economic, and political dynamics of India in $21 \mathrm{st}$ century, has induced redefinitions of domestic relationships, reproductive functions of women and motherhood. Women are struggling on front of motherhood and reproductive choices and negotiating between the various forms of domination that constrains their life.

The question here is how modern educated Indian women brought up in traditional enclosures, with orthodox ideologies and normative customs come out of their closet claiming right to make affirmative choice regarding the most crucial decision of their life. Today's women's reproduction roles are contested and negotiated in the backdrop of conflicting claims and practices.

\section{Literature Review}

Motherhood is more important than work and that all women should be able to work across their lifespan, as per the findings of Marks and Houston. They have explored the attitudes of mothers who worked full time, those who worked part-time and those who did no paid work. (Marks \& Houston, 2002). It is maintained that motherhood carries both oppressive and fulfilling elements. Rowbotham opines that motherhood must be freely chosen and socially transferred. The decision whether to have or have not a child must be a conscious decision. There is a tremendous release in the accounts of struggles, dependence, exhaustion and rage. Over a period of time women has begun talking about the most challenging aspect of mothering: depression, derangement and violence (Rowbotham, 1989). Reproductive decisions are an outcome of many conflicting reasons and thoughts. Rebecca Kukla argues that "reproductive decisions necessarily take place in an arena of received meanings; values, and norms; ascriptions of liability and the identification of parental virtues must be subject to a nuanced social analysis" (Mahowald, 2007). Reproductive decision indeed is not a single contributing factor; rather values such as, family norms, social status etc are associated in the process of decision making. As Tamar Kricheli -katz have documented substantial penalties linked with motherhood and suggest that discrimination plays an important role in producing them. It experiments with wage analysis and found that mothers are penalised more where motherhood is perceived to be a woman's choice (Krichellikatz, 2012). The meaning of motherhood and the choices open to her have been quite contentious. Feminists have regarded women's acquisition of control over their own reproduction not only as a necessary step to individual freedom and autonomy, but also as a fundamental condition to overcome patriarchal control and improve situation of 
women as a group (Petchesky, 1995). There has been emergence of various technologies influencing the reproductive decision and motherhood. It has been argued that assisted reproductive technologies (ART) has further decomposed biological and social motherhood and has altered the meaning of motherhood and reproduction. It further lay down that despite the rhetoric of choice surrounding ART, these technologies have not increased women's reproductive freedom (Neyer \& Bernardi, 2011). Reproductive decisions have not only been regulated by technologies but even with career. Millar establishes the effects of motherhood timing on female career path. It studies the effects of delay on career and finds that fertility delay after adolescence improves career outcomes and increases career earnings by $9 \%$. Results of the study indicated that women could achieve higher earnings by delaying motherhood timing in the twenties and early thirties (Miller, 2011). Delaying in motherhood is also because many times it is linked to career aspirations and educational goals. Dye had proposed this argument that educational goals and career makes women decide for delay in child bearing (Dye, 2008). Career remains an important component for deciding motherhood as a choice. Grady \& McCarthy study findings state that a deep sense of motherhood was evident as in children were priority for such women; but career was of equal importance as they sought stimulation, challenges, achievement and enrichment in their work. The study reports that a complex relationship of work-related dynamics and personal factors shaped the meaning for these women amid competing priorities of work, family and individual lives (Grady \& McCarthy, 2008). With such conflicting considerations of work family and self the image of motherhood has been full of complexities. As "We are bombarded on all sides with the image of motherhood as a radiant woman who has achieved her ultimate fulfilment by holding a sweet- smelling, sleeping baby in her arms. The reality is more likely to be a harassed dishevelled mum with a foul-smelling yelling baby. We think the shock effect of this gap between the myth and the reality is underestimated and not discussed enough. We seem committed to a conspiracy of silence" (Muir, 1970).

Motherhood image has been overshadowed by many relationships, whether it is relation between child and the mother or nanny, child and mother. Hardin and Hardin throw light on how the relationship of mother and nanny influences self esteem of the child. It is mentioned that mother's denial to child's emotional attachment to a nanny, people are unable to validate the child's loss of a caregiver. A secure mother-attachment leads to a secure relationship between infant and caregiver, while a close relationship to the caregiver improves that with the mother (Hardin \& $\mathrm{H}$, 2000) Motherhood and child covers the whole sphere of influence. For child it is only the mother but for a mother it is at par with voluntary slavery, as per the writings of Claire Dischen. He wrote that women have quite different attitudes to motherhood when they are in 20 s and when they are in 30s (Duchen, 1986). Attitudes of mothers and that of society are on quite different foundations. How modern motherhood need to accept the basket of responsibility many times influenced by society itself. As perceptions about Indian motherhood have been expressed by Judy Whitehead, that women are expected to be 'an educated mother aware of home science and hygiene' who can smoothly 'combine the self-sacrificing traditional mother image, the education autonomy of the vedic woman and hygienically informed "modern" motherhood (Whitehead, 1995). In Indian society, respect, recognition and reputation linked with economic status of a person. As generally men are more involved in economic generation, it is assumed that a marriageable age woman should get married to a man who has more economic worth. Even as stated by Jennifer Blomstrom that woman is often conditioned to believe that the best way to achieve high social status is to marry a man of high status (Blomstrom, 1999).

\section{Methodology}

\section{Design}

We have drawn our paper on phenomenological and ethnographic approaches to qualitative research, using intensive interviews (Lofland \& Lofland, 1994) because we wanted to know the factors that determine reproductive and early motherhood choices among married Indian working and non- working women. The objective of the study is to explore how education and employment can impact the psyche of Indian women when it comes to making choices related to reproduction and motherhood. In this case, we interviewed 20 married Indian middle-class women and after interviews themes began to reoccur in the data.

\section{Participants}

The criteria for participating in this study were two-fold, one that they had to be married women and secondly they either were working or non- working. The term "working" here denotes a woman, who is engaged in economic pursuits and had to spend around 6-8 hours in her professional spaces, outside her home. "Non-working" term denotes woman not engaged in any kind of economic activity outside home. Such woman stays generally at home and had primary responsibility to take care of home and children. In our Paper we have used the term "earlymotherhood" which means, when woman considers motherhood as a choice within first, second or third years of her marriage. Participants were solicited via community support. Among all participants, 10 were working and 10 were non-working. The sample of these 20 women was in age group of 21 to 35 years. Sample was further classified into four categories on the basis of their marital period. The first category comprises of women married for less than 1 year; second category of women married one year - five yrs.; third category married for five years- ten yrs.; and lastly fourth category of married for more than 10 years and above. Their educational qualifications ranged from holding a graduate degree to doctorate including professional degree as well. To some extent religious diversity (although not intentional) can also be seen in sample.

Participants were informed that their data is used solely for research purpose and they consented for the same verbally. This informed consent technique revealed that participants had a clear understanding of the study and were willing to 
proceed and agreed to reveal personal information about them.

\section{Data Collection}

Personal interviews were conducted in the district of Gautam Budh Nagar combining snow ball and convenient sampling methods. The semi-structured interview included 10 questions related to demography for example age, marital status, number of children, education, place of origin, occupation and their motivations and desires, experiences about motherhood. In addition to pre-determined questions, relevant follow-up and clarifying questions were asked to elicit greater detail. These interviews were conducted face to face during November 2019 to January 2020. The interviews were conducted in both Hindi/ English language. Each woman was interviewed for about $35-45$ minutes. The participants were predominantly middle class and identified themselves as heterosexuals.

As qualitative researches do not claim to look at their material from neutral lens (Weiss, 1994), both of us have written down the statement and included discussion of the biases as they related to data analysis in the following manner: First we read the transcripts to understand the material. In a second reading, we took notes in the margins regarding significant themes for example repeated messages from participants. All this was then transferred to a grid which allowed us to view the subjects' responses by question (down) and by individual (across). To add to the rigor the entire process was captured in memo writing and then we analysed and discussed the responses at frequent intervals.

\section{Findings}

Study revealed interesting results depicting affirmative choices of reproduction and motherhood among working and non-working women. We spoke to non-working and working mothers to gauge their concerns and tensions in making such choices. This comparative strategy allowed us to examine tensions between conflicting ideas relating to individuality, empowerment, femininity, and motherhood from the perspective of participants.

Study brings forth narratives of non-working women that has underpinnings in sociological, cultural and religious beliefs, where they have been assigned the role of key player in up keeping the traditions, family lineage and value system. This is further garnished by self-assumed roles which are shaped by parent's outlook, dominance of social and religious orthodox beliefs in family and educational constraints.

The general and popular ideological believes in Indian society related to motherhood and reproductive roles doesn't give many choices to women. The situation is more pathetic among poor, uneducated women as the technological advancement and modernism have not increased their reproductive freedom. They end up landing into unwanted pregnancies.

Middle class Indian women end up making these choices under multiple and overlapping controls. Own ideological surmise related to motherhood, societal pressure flowing from parents and in-laws, assumptions that motherhood is a breeding ground of growing stability and social influence, coaxes and cajoles women to make quick choice of reproduction.

Prime factors responsible for choosing early motherhood ranged variably but the prime theme which has emerged from the research indicates that non-working women choose motherhood over career/ profession. Among all the 10 nonworking participants, besides 2 , rest all 8 women had been through the process of motherhood. One out of two excluded, one participant couldn't conceive due to medical reasons; and another one married for less than one year intentionally didn't plan for motherhood. Among 8 participants who are mothers; 2 participants chose early reproduction because of family and societal pressure; 1 participant chose early reproduction as she had no career orientation; 2 participants believed early motherhood shall enhance their social influence \& lastly 1 participant choose motherhood for love of it.

Interview transcripts of all 20 women were thematically analysed and brief results shown in tables as follows:

Table 1 Classification showing Reproduction \& Motherhood choices among non-working Indian women

\begin{tabular}{|c|c|c|c|c|c|c|}
\hline $\begin{array}{l}\text { S.n } \\
\text { o. }\end{array}$ & $\begin{array}{l}\text { Name of respondent/ } \\
\text { Religious identity/ } \\
\text { Place of origin) }\end{array}$ & Age & Marital period & $\begin{array}{l}\text { No. } \\
\text { of } \\
\text { childr } \\
\text { en }\end{array}$ & $\begin{array}{l}\text { Is early reproduction / } \\
\text { motherhood priority } \\
\text { for you in marriage? }\end{array}$ & Reason \\
\hline 1. & $\begin{array}{l}\text { Latika Semwal } \\
\text { Hindu) }\end{array}$ & 22 & $\begin{array}{l}\text { Less than one } \\
\text { year }\end{array}$ & 0 & No & $\begin{array}{l}\text { It is too early, not } \\
\text { even one yr. post } \\
\text { marriage. }\end{array}$ \\
\hline 2 & Kusum Rani ( Hindu) & 24 & $\begin{array}{l}\text { Less than one } \\
\text { year }\end{array}$ & 1 & Yes & $\begin{array}{l}\text { Enhancement in social } \\
\text { influence. }\end{array}$ \\
\hline 3 & Ashima Biwi( Muslim) & 31 & $\begin{array}{l}\text { more than } 2 \text { yrs- } \\
5 \text { yrs }\end{array}$ & 3 & Yes & $\begin{array}{l}\text { Societal and family } \\
\text { pressure }\end{array}$ \\
\hline 4 & $\begin{array}{l}\text { Christine Joseph } \quad( \\
\text { Christian) }\end{array}$ & 33 & $\begin{array}{l}\text { more than } 2 \text { yrs- } \\
5 \text { yrs }\end{array}$ & 2 & Yes & $\begin{array}{l}\text { Desire } \\
\text { motherhood }\end{array}$ \\
\hline 5 & $\begin{array}{l}\text { P. Saveetha Ram ( } \\
\text { Hindu) }\end{array}$ & 31 & $\begin{array}{l}\text { more than } 2 \text { yrs- } \\
5 \text { yrs }\end{array}$ & 2 & Yes & $\begin{array}{l}\text { Motherhood brings } \\
\text { stability in marriage. }\end{array}$ \\
\hline
\end{tabular}




\begin{tabular}{|l|l|l|l|l|l|l|}
\hline 6 & Pooja Gupta (Hindu) & 30 & $\begin{array}{l}\text { More than 5 } \\
\text { yrs- 10 yrs }\end{array}$ & 2 & Yes & $\begin{array}{l}\text { Nothing better to do, } \\
\text { asn't career } \\
\text { oriented. }\end{array}$ \\
\hline 7 & Reena Mathur (Hindu) & 32 & $\begin{array}{l}\text { More than 5 yrs } \\
-10 \text { yrs }\end{array}$ & 0 & Yes & $\begin{array}{l}\text { Unable to conceive } \\
\text { due to medical } \\
\text { reasons. }\end{array}$ \\
\hline 8 & $\begin{array}{l}\text { Lalmingliani } \\
\text { (Christian) }\end{array}$ & 31 & $\begin{array}{l}\text { More than 5 yrs } \\
-10 \text { yrs }\end{array}$ & 1 & Yes & $\begin{array}{l}\text { To strengthen the } \\
\text { bond betwen couple } \\
\text { and bring stability }\end{array}$ \\
\hline 9 & $\begin{array}{l}\text { Shafina sheikh ( } \\
\text { Muslim) }\end{array}$ & 34 & 10 yrs \& above & 2 & Yes & $\begin{array}{l}\text { Assumed it will } \\
\text { enhance social } \\
\text { influence. }\end{array}$ \\
\hline 10 & $\begin{array}{l}\text { Rosy } \\
\text { (Christian) }\end{array}$ & 35 & 10 yrs \& above & 2 & Yes & $\begin{array}{l}\text { Family and societal } \\
\text { pressure. }\end{array}$ \\
\hline
\end{tabular}

Table 2 Classification showing Reproduction \& Motherhood choices among working Indian women

\begin{tabular}{|c|c|c|c|c|c|c|}
\hline S.no. & $\begin{array}{l}\text { Name of respondent/ } \\
\text { Religious identity/ region) }\end{array}$ & Age & Marital period & $\begin{array}{l}\text { No. of } \\
\text { children }\end{array}$ & $\begin{array}{l}\text { Was early } \\
\text { reproduction } \\
\text { motherhood priority } \\
\text { for you in marriage? }\end{array}$ & Reason \\
\hline 1. & Shweta Sharma ( Hindu) & 24 & Less than one year & 0 & No. & $\begin{array}{l}\text { Motherhood will be too early, want to } \\
\text { enjoy life. }\end{array}$ \\
\hline 2 & $\begin{array}{l}\text { Rathima Subramaniyam ( } \\
\text { Hindu) }\end{array}$ & 27 & Less than one year & 0 & No. & Goal is to establish in career first \\
\hline 3 & Palak Negi ( Hindu) & 29 & more than 2 yrs- 5 yrs & 0 & No. & $\begin{array}{l}\text { Career promotion is crucial at this } \\
\text { stage. }\end{array}$ \\
\hline 4 & $\begin{array}{l}\text { Rima chakraborty } \\
\text { Hindu) }\end{array}$ & 30 & more than 2 yrs- 5 yrs & 0 & No. & Want to earn my doctorate degree first. \\
\hline 5 & Afreen Khan ( Mulim) & 32 & more than 2 yrs- 5 yrs & 1 & No & $\begin{array}{l}\text { Wasn't aware of the challenges } \\
\text { involved in motherhood. }\end{array}$ \\
\hline 6 & Lalroutlangi ( Christian ) & 34 & More than 5 yrs- 10 yrs & 1 & No & Busy in higher studies. \\
\hline 7 & Rosy Joseph ( Christian) & 34 & More than $5 \mathrm{yrs}-10 \mathrm{yrs}$ & 1 & No & $\begin{array}{l}\text { Was busy in my profession which } \\
\text { involved lot of touring job. }\end{array}$ \\
\hline 8 & $\begin{array}{l}\text { Kusum Bharnagar } \\
\text { Hindu) }\end{array}$ & 35 & More than $5 \mathrm{yrs}-10 \mathrm{yrs}$ & 2 & No & Self -accomplishment. \\
\hline 9 & Farha Jameel ( Muslim) & 33 & 10 yrs \& above & 1 & No & Preparing for competitive services. \\
\hline 10 & $\begin{array}{l}\text { Babita Sinha ( Hindu, } \\
\text { North India) }\end{array}$ & 35 & 10 yrs \& above & 0 & $\begin{array}{l}\text { No it wasn't then, but } \\
\text { now it's an absolute } \\
\text { necessity }\end{array}$ & Biological clock is ticking too fast. \\
\hline
\end{tabular}

Mother of two kids, Christine Joseph sought to reason, why she longed for a child in terms of an inward existential quest rather than seeing the desire to mother as a result of external 'conditioning'. She narrates "I have been trying to work out what has been driving me to have a child, what makes it so fulfilling for me.... Although various reasons were poured over me justifying early motherhood such as: ability and strength needed to raise a child in is comparatively more when women are in their prime youth, it results in quick acceptance by family and society and it's part of belonging to natural cycles of life and death etc. I was told that the child shall fill the missing love and warmth inside me, a kind of deep loneliness as my mother passed away when I was a teenager. Today I see that having a baby has been a way of exploring a part of myself, of somehow reliving and reshaping my own childhood and through it perhaps getting a bit mature".

Many non-working women take great pride in sacrificing their careers for their families. This sense of pride is echoed in Pooja Gupta dialogue, a 30-year-old mother of 2 children shares "I have no guilt of being a housewife. My husband earns decently and if I choose not to go out for economic engagement, this does not mean I am worthless. I do all home chores myself" What I do is not only seen as a labour of love by my husband, rather he says my savings are my income (laugh out loud)". She continues giggling and re- 
join, "After all, I save all the money which he would have to give to some outsider, if I move out of the house for work)." While other non-working women do not share the same emotion, there are others who are tensed and in their accounts several times mention the struggle, dependence, exhaustion and rage due to their economic dependency on their spouse. Not all the women who chose early motherhood and reproduction over career prospects are contented about their decision. The narrative of Shafina sheikh, 34-year-old, explicitly depicts dissatisfaction, " $M y$ assumption of equality and the reality of my domestic confinement was acute. My belongingness to a conservative Muslim family made me leave study to marry a person who eventually divorced me. I was a weak, shattered, and hopeless mother. I realised the value of education after I had to face the struggle of unemployment and stigma attached to my social status. As a single mother I have experienced economic hardships and social harassment".

This narrative of Shafina reaffirms that "family is the fundamental unit of the Islamic society and women are its fundamental elements'. Studies have shown that not only in India but in other Muslim countries like Pakistan, Malaysia and Iran Muslim women have prioritised family over their professional desires (Rahmani \& Tayebinia, Women Reflexive Identity, 2018)

Prime factor responsible for delaying in early motherhood is engulfed in concepts of liberal feminism, personal autonomy and a desire of professional accomplishments among educated middle class working women. The prime theme which has surfaced up indicates that Indian middle class educated working women choose career and profession over motherhood. Among all 10 working participants, 4 participants below the age of 30 have no plans to choose motherhood over their career as they believe it will cast heavy penalty on their career goals; 1 participant could not conceive due to medical reasons. Other 5 participant who are mothers, became so after achieving their desired career goals.

Not only in India but even in European studies pondered on discourses related to penalty with which motherhood is perceived among European women. Vaneesa Gash discusses competing explanations regarding mothers exchanging lower wages for 'mother friendly' working conditions. A history of lower pay for mothers across various European countries also shakes the willingness of ambitious women in sacrificing their career for motherhood (Gash, 2009).

Such dispassionateness related to early motherhood is ubiquitous in assertions of middle class Indian working women. Attacking the myth around seeking happiness through motherhood, Palak Negi a Software Engineer educated in small town of Haridwar shares- "I defy and contest the idea that happiness comes only through motherhood which denies a range of possibilities. Achieving desired promotion in career is more liberating and enriching experience for me".

Desire to maintain a work life balance is also important for Indian women wishing to have a personal and professional fulfilling life. Crompton (1999) described that in the beginning of the twenty-first century, work-life balance did not receive much attention and seemed to be less challenging due to two reasons (Crompton, 1999). First, employment was limited only to a male full-time worker and they were considered as the breadwinner. Second, it was a traditional trend that women involved themselves in more unpaid work such as nurturing, caring, and domestic work (Prithi \& Vasumathi, 2018). Work life balance issues arose when increased number of women workers and dual-earner couples entered workforce in various employment sectors (Burke \& Greenglass, 1987). Studies have shown that a successful work-life balance leads to achievement of personal and professional career goals (Matheswaran \& Hemlata, 2015).

Some women fail to achieve their work life balance due to incapability to set priorities (Santhana \& Gopinath, 2013). Other woman takes a decisive step and appears to cluster in occupations with job attributes supportive of work life balance. As a result, they may 'trade down' to part time jobs in pursuit of work life balance. They either change their profession or take post of lower occupational worth which gives fewer wages (Connolly \& Gregory, 2008). Similar is the anecdote of Afreen Khan, who has switched over her occupation post her childbirth. Being contented she share "I have master's degree in business administration. I have always worked in corporate sector and fetched good salary and perk, but after Samaira's birth (her daughter) my priority has changed (cuddles her baby - samaira) I have taken up school teaching in pursuit of work life balance".

The story of Afreen Khan bring into limelight societal perception and stereotyping related to gender and occupation. Teaching is believed to be the most suitable profession for women across all classes, although it is an underrated and under paid profession in India.

Baston (2006) discusses how the education profession in Germany is feminised and how this feminisation has affected its pay and social prestige (Basten, 2006). Confronting and changing stereotypes is therefore central to evolving how both women and men can operate in society and in the economy attaining their full potential. The present government under the leadership of Prime Minister Mr. Narendra Modi is running several women and girl upliftment flagships programmes across all ages. One such programme is ' Beti Bachao, Beti padhao', to simplify 'Save daughters, educate daughters'. Such initiatives by the government encourage parents to provide equal opportunities to their wards despite of gender differences. Education in turn leads to empowerment, economic independence, and social security. Once educated women get empowered, she wishes to enjoy her independence with less liabilities.

Shweta appeared stupefied when she was asked about her plans of motherhood, she said: "Hey!!! I am just 24 years old. My parents spared no expenses for my education. I got married early coz I was in love and dating someone who is my husband now, but this doesn't mean I am going to put my career at stake. it's only love and work in air!!!" The studies have shown that a working woman enjoys her personal life and succeeds in her professional life which leads to positive work life balance (Prithi \& Vasumathi, Work Life Balance of women employees , 2018).

Babita Sinha, who is a 35 years, accounts the canvass, the downside of opting motherhood, "It's been 10 yrs. that I am married and successful... initial 5-7 yrs. post marriage, I spend in shaping my career, received several promotions in office, but my personal commendation as a women is due. 
I am under IVF Treatment since last 2 years, keeping fingers crossed. Hopes, god bless us with a little bundle of joy".

\section{Limitation Of The Study}

We realised that this study has two limitations. Firstly, sample size is small, comprising narratives of only 20 women residing in Gautama Budh Nagar District of Northern India. With an analysis of this sample, the results may not be generalised for all married, educated, Indian middle class working and non -working women in India. Secondly, we trust all participants have been honest in sharing their attitudes and drive relating to motherhood choices, but possibility of skewed or misinformation cannot be ruled out completely.

Changing patterns of women family priorities among upcoming generation of Indian women could be more relevant research topic in near future. The themes evolved in this study can be taken up further for both quantitative and qualitative analysis in other regions of India, to reaffirm and reassure the analysis drawn in this study.

\section{Conclusion}

The question what makes a woman? Is it sexual intimacy or conception of child birth? Whether Procreation depends on relationships or decision making? What is the major responsibilities of an educated women? With times, women has become more autonomous, independent, and selfsufficient. For Indian women, family has been the most important and primary locus. Although times and perspective have been changing but still largely domestic and reproductive roles define their status and position within and beyond family. They are the protectors of tradition and ritual practices. Yet, women have taken up charge by rejecting the traditional role and have begun redefining new roles in new age. Strong economic backgrounds have provided an upsurge to women to re-decide their fields of choice. The choice of taking up career and financial stability on the top priority has overtaken the traditional domestic boundaries and reproductive roles in newer perception peculiarities.

"God could not be everywhere and therefore he made mothers". Jewish proverb reminds us that we need to entrust ourselves to mothers and we are responsible how future mothers are born, how they grow up into adults and how much free environment we can provide for their choices.

\section{References}

[1] Basten, C. (2006). A Feminised Profession: women in the teaching profession. Educational Studies , 55-62.

[2] Blomstrom, J. (1999, February). A different reprodcutive choice. Off our backs - a women newsjournal , 29 (No. 2), p. 6.
[3] Burke, R., \& Greenglass, E. (1987). Work and family. International Review of Industrial and Organizational Psychology , 273-320.

[4] Connolly, S., \& Gregory, M. (2008). Moving down: Women's part time work and occupational change in Britain, 19912001. The Economic Journal , 118(526), F52-F62.

[5] Crompton, R. (1999). Restructuring gender relations and employment. Oxford University Press.

[6] Duchen, C. (1986). Feminism in France, From May '68 to Mitterand Londan. Routledge and Kegan Paul.

[7] Dye, j. L. (2008). Fertility of American Women:2006. US Census Bureau.

[8] Eshleman, J. (2003). The Family. Boston: Allyn \& Bacon.

[9] Gash, V. (2009). Sacrificing their careers for their families? An analysis of the penalty to motherhood in Europe. Social Indicators Research , 93 (No.3), 569-586.

[10] Grady, G., \& McCarthy, A. M. (2008). Work-life integration: experiences of midcareer professional working mothers. Journal of managerial Psychology , 23 (No.5), 599-622.

[11] Hardin, H. T., \& H, H. D. (2000). On the vicissitudes of early primary surrogate mothering II: Loss of the surrogate mother and arrest of mourning. Journal of American Psychoanalytic Association , 48, 1229-1258.

[12] Hayami, Y. (1998). Motherhood Redefined: Women's choice on family rituals and reproduction in the periphery of Thailand. SOJOURN , B (No. 2), 242-262.

[13] Hayami, Y. (1998). Motherhood Redefined: Women's Choices on Family Rituals and Reproduction in the Peripheries of Thailand. SOJORN:Journal of Social Issues in Southeast Asia , 13 (No. 2), 242.

[14] Krichelli-katz, T. (2012). Choice, Discrimination and the Motherhood 
Penalty. Law \& Society Review , 46, 557587.

[15] Lofland, J., \& Lofland, L. (1994). Analysing social settings: A guide to qualitative research . Belmount: Wadsworth Publishing.

[16] Mahowald, M. (2007). Mass Hysteria : Medicine, Culture and Mothers' Bodies By Rebecca Kukla, Lanhem. Hypatia , 22 (3), $216-218$.

[17] Marks, G., \& Houston, D. M. (2002). Attitudes towards work and motherhood held by working and non-working mother. Work, Employment \& Society , 16 (3), $523-536$.

[18] Matheswaran, V., \& Hemlata, V. (2015). A Study on work life balance for women employees in public and private sector schools in Itruvallur district. International Journal of Research in Management and Technology , 196-206.

[19] Miller, A. R. (2011). The effects of motherhood timing on career path. Journal of Population Economics , 24 (3), 1071110.

[20] Muir, A. (1970, January ). On Having Children. Shrew .

[21] Neyer, G., \& Bernardi, L. (2011). Feminist Perspectives on Motherhood and Reproduction. Historical Social Research , 36 (2 (136)), 162-176.

[22] Petchesky， R. P. (1995). The body as property: A feminist re-vision. In conceiving the new world order. The global politics of reproduction. (F. D. Ginsburg, Ed.) Berkeley: University of California Press.

[23] Prithi, S., \& Vasumathi, A. (2018). The Influence of Demographic Profile on Work Life Balance of Women Employees in Tannery Industry - An empirical Study. Pertanika Journal of Social Science and Humanities , 26(1), 259-284.

[24] Prithi, S., \& Vasumathi, A. (2018). The Influence of Demographic profile on Work Life Balance of women Employees in Tannery Industry- An empirical study.
Pertanika Journal of Social Science and Humanities , 26(1), 259-284.

[25] Rahmani, J., \& Tayebinia, M. (2018). Women's Reflexive Identity and Spirituality Case study: Iranian Employed, Degree-holder women. Pertanika Journal of Social Science \& Humanities , 26(T), 197-214.

[26] Rahmani, J., \& Tayebinia, M. (2018). Women's Reflexive Identity and spirituality, Case Study: Iranian Employed, Degree-holder women. Pertanika Journal of Social Sciences \& Humanities , 26 (T) (197-214), 201.

[27] Rowbotham, S. (1989). To be or Not to be : The Dilemmas of Mothering. Feminist Review , 31, 82-93.

[28] Santhana, L., \& Gopinath, S. (2013). Work Life balance of women employees with reference to teaching faculties. International Monthly referred Journal of Research in management and Technology, 2 (3), 53-62.

[29] Weiss, R. (1994). Learning from strangers:The art and method of qualitative interview studies. New York : The Free Press.

[30] Whitehead, J. (1995). Modernising the motherrhood archetype. Contributions to Indian Sociology , 29 (1\& 2).

[31] Wolf, D., \& Gardner, H. (1981). Early Language and Intervention. (D.D.Bricker, Ed.) Baltimore: University Oark Press. 